\title{
ZRÓWNOWAŻONY ROZWÓJ - TREND CZY ELEMENT NOWOCZESNEGO ZARZĄDZANIA SAMORZĄDEM
}

\author{
Aneta Herbuś, Beata Ślusarczyk \\ Politechnika Częstochowska \\ Wydział Zarządzania
}

\begin{abstract}
Streszczenie: Celem artykułu jest wskazanie znaczenia koncepcji zrównoważonego rozwoju w procesie zarządzania samorządem. W obecnej sytuacji gospodarczej samorządy, które w znacznym stopniu różnią się od przedsiębiorstw, zmuszone są ze sobą konkurować. Rywalizują zarówno w kwestiach ekonomiczno-gospodarczych, społecznych, kulturalnych, jak i ekologicznych. Chcąc sprostać wymaganiom i potrzebom zgłaszanym przez różne grupy interesariuszy, angażują się w wiele różnorodnych inicjatyw. Zarówno społeczność lokalna, jak i inwestorzy czy lokalni przedsiębiorcy wymagają, aby samorząd był zarządzany w sposób efektywny i zrównoważony. Dlatego właśnie jednostki samorządu terytorialnego coraz częściej wykorzystują koncepcję zrównoważonego rozwoju w procesie zarządzania i na wszystkich jego poziomach.
\end{abstract}

Słowa kluczowe: jednostka samorządu terytorialnego, zrównoważony rozwój samorządu terytorialnego, samorząd, zarządzanie samorządem, zrównoważony rozwój

DOI: $10.17512 /$ znpcz.2018.1.01

\section{Wprowadzenie}

Odnosząc się do zmian zachodzących we współczesnym świecie, zauważyć można znaczną degradację środowiska, zbytnie zużycie zasobów naturalnych oraz wyjątkowo konsumpcyjny tryb życia. W konsekwencji w jednostkach samorządu terytorialnego władze podejmują starania celem rozwoju w sposób zrównoważony. Coraz częściej wprowadzają do swoich strategii zapisy regulujące wykorzystanie zasobów naturalnych w taki sposób, aby zużycie dóbr pozwoliło zarówno na realizację potrzeb pokoleń obecnych, jak i przyszłych. W wielu samorządach można znaleźć przykłady dobrych praktyk z zakresu zrównoważonego rozwoju, gdyż dążą one do uzyskania miana miast zrównoważonych.

\section{Zarządzanie jednostką samorządu terytorialnego}

Zgodnie z definicją wskazaną w Europejskiej Karcie Samorządu samorząd terytorialny to „prawo i zdolność społeczności lokalnej, w granicach określonych prawem, do kierowania i zarządzania zasadniczą częścią spraw publicznych na ich własną odpowiedzialność i w interesie ich mieszkańców" (Europejska Karta Samorządu Terytorialnego...). Aby samorząd mógł się rozwijać, musi być świadomie zarządzany, a proces ten musi obejmować szereg kwestii związanych z jego specyfiką i kompetencjami (Wojciechowski 2003, s. 8). Zarządzanie, stające się podsta- 
wowym procesem rozwoju samorządu, należy rozumieć jako katalog działań (Rysunek 1), które odnoszą się do zasobów organizacji (także jednostki samorządu terytorialnego) i mają za zadanie realizację wyznaczonych celów i zamierzeń (Griffin 2005, s. 6).

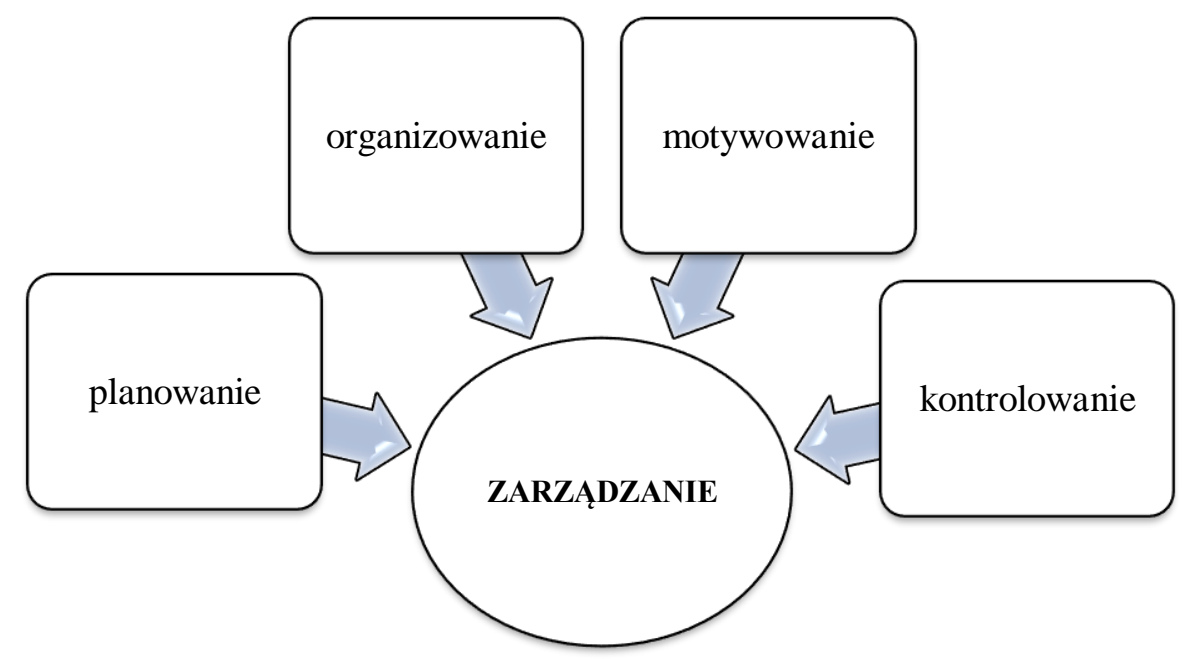

\section{Rysunek 1. Elementy procesu zarządzania}

Źródło: Opracowanie własne na podstawie (Griffin 2013, s. 8)

Podkreślenia wymaga fakt, iż proces zarządzania jest na tyle uniwersalny, że jego elementy wykorzystywane są przez wszystkie typy organizacji, tj. przedsiębiorstwa, stowarzyszenia, fundacje, jak i jednostki samorządu terytorialnego. Zarządzanie jednostką samorządu terytorialnego należy rozumieć jako proces, w którym władze samorządowe wywierają wpływ na zasoby terytorialne (ludzi, jednostki, organizacje umiejscowione na danym terytorium) w celu realizacji zadań publicznych (Wojciechowski 2003, s. 11-12). Oznacza to, iż władze samorządowe tak planują, organizują oraz kontrolują podejmowane działania, aby skutecznie realizować zadania, które zaspokoją potrzeby lokalnych interesariuszy. Prawidłowo zrealizowane zadania publiczne stanowią odpowiedź na potrzeby zarówno indywidualne, jak i grupowe, zgłaszane przez lokalne społeczeństwo (Gawroński 2010, s. 37). Ponieważ z procesem zarządzania nierozerwalnie związany jest etap wyznaczenia celów, władze samorządowe zobowiązane są tak skonstruować kierunki rozwoju jednostki samorządu terytorialnego, aby móc $\mathrm{w}$ pełni realizować zadania publiczne i osiągać jak najlepsze rezultaty. W Tabeli 1 przedstawiono główne cele zarządzania samorządem, jakie wskazuje A. Noworól. 
Tabela 1. Cele zarządzania jednostką samorządu terytorialnego

\begin{tabular}{|c|c|}
\hline Cele & Charakterystyka \\
\hline społeczno-polityczne & $\begin{array}{l}\text { sprostanie wymaganiom społeczności lokalnej; } \\
\text { odpowiedź na zgłaszane potrzeby mieszkańców; } \\
\text { (szczególne znaczenie koncepcji społecznej } \\
\text { odpowiedzialności samorządu) }\end{array}$ \\
\hline gospodarcze & $\begin{array}{l}\text { zaspokojenie potrzeb zgłaszanych przez potencjalnych } \\
\text { inwestorów; } \\
\text { tworzenie warunków przyjaznych nowym inwestycjom; } \\
\text { kreowanie środowiska wpierającego lokalną } \\
\text { przedsiębiorczość; } \\
\text { tworzenie warunków rozwojowych dla samorządu jako } \\
\text { jednostki }\end{array}$ \\
\hline $\begin{array}{r}\text { środowiskowe } \\
- \\
-\end{array}$ & $\begin{array}{l}\text { racjonalne i oszczędne wykorzystywanie zasobów } \\
\text { środowiska naturalnego; } \\
\text { zrównoważone planowanie rozwoju w aspekcie } \\
\text { środowiskowym; } \\
\text { zrównoważone planowanie przestrzenne; (szczególne } \\
\text { znaczenie koncepcji zrównoważonego rozwoju) }\end{array}$ \\
\hline
\end{tabular}

Źródło: Opraeowanie własne na podstawie (Noworól 2007, s. 74-75; Noworól 2006, s. 70)

Prawidłowo określone przez samorząd cele realizowane poprzez zadania publiczne pozwolą na skuteczne zarządzanie jednostką. Istotnym jest, iż w przypadku samorządu do procesu tego powinny być zaangażowane nie tylko władze samorządowe, lecz także poszczególne grupy lokalnych interesariuszy (mieszkańcy, samorządowcy, organizacje wspierania biznesu, organizacje pozarządowe czy przedsiębiorcy). Ważną rolę $\mathrm{w}$ procesie zarządzania samorządem odgrywa opracowana strategia rozwoju (Sekuła (red.) 2007, s. 198), która stanowi dokument systematyzujący obrane cele i kierunki działania. Do podstawowych funkcji strategii samorządu zalicza się m.in. (Ziółkowski 2003, s. 66):

regulacyjną,

napędzającą rozwój lokalny,

informacyjną,

promocyjną,

koordynacyjną,

kontrolną,

ochronną,

racjonalizującą.

Podkreślenia wymaga fakt, iż współczesne samorządy budują swoje strategie rozwoju na podstawie symbiozy i skutecznego łączenia kwestii społecznych, gospodarczych, politycznych i środowiskowych. Strategie te tworzone są zatem w oparciu o zasady zrównoważanego rozwoju przy odpowiedzialnym wykorzystaniu zasobów (Kronenberg, Bergier 2010, s. 220). 


\section{Zrównoważony rozwój jednostki samorządu terytorialnego}

Szybko postępujące zmiany zachodzące w światowej gospodarce wymogły na różnorodnych jednostkach organizacyjnych konieczność poszukiwania nowych koncepcji niezbędnych do osiągnięcia sukcesu. W zarządzaniu zarówno przedsiębiorstwem, jak i jednostką terytorialną pojawiła się konieczność wprowadzenia nowych idei, będących odpowiedzią na zmieniający się świat i postawy społeczeństwa. W konsekwencji tych zmian w 1987 roku, w oparciu o zasady równowagi i poszanowania otoczenia, w raporcie Brundtland przedstawiono koncepcję zrównoważonego rozwoju. Zrównoważony rozwój został wówczas zdefiniowany jako rozwój mający za zadanie zaspokoić potrzeby obecnego pokolenia przy jednoczesnym poszanowaniu zasobów dla przyszłych pokoleń (Mierzejewska 2015, s. 5). Szerzej koncepcję zrównoważonego rozwoju definiuje natomiast ustawa Prawo ochrony środowiska, według której jest to rozwój o charakterze społecznogospodarczym. Jego fundamenty stanowią natomiast idee gospodarcze, społeczne i polityczne przy jednoczesnym szacunku dla środowiska i jego zasobów (Skowron-Grabowska 2014, s. 24-32; Kot, Brzeziński 2015, s. 101-112). Zgodnie z ideą zrównoważonego rozwoju zachowany musi zostać ład pomiędzy obecnymi, jak i przyszłymi pokoleniami (Skowron-Grabowska 2014, s. 24-32; Kot, Brzeziński 2015, s. 101-112). Podsumowując, można stwierdzić, iż zrównoważony rozwój opiera się na współdziałaniu trzech aspektów, które w perspektywie jednostki samorządu terytorialnego należy rozszerzyć o jeszcze jeden istotny element $-\mathrm{tj}$. aspekt planistyczny (Rysunek 2).

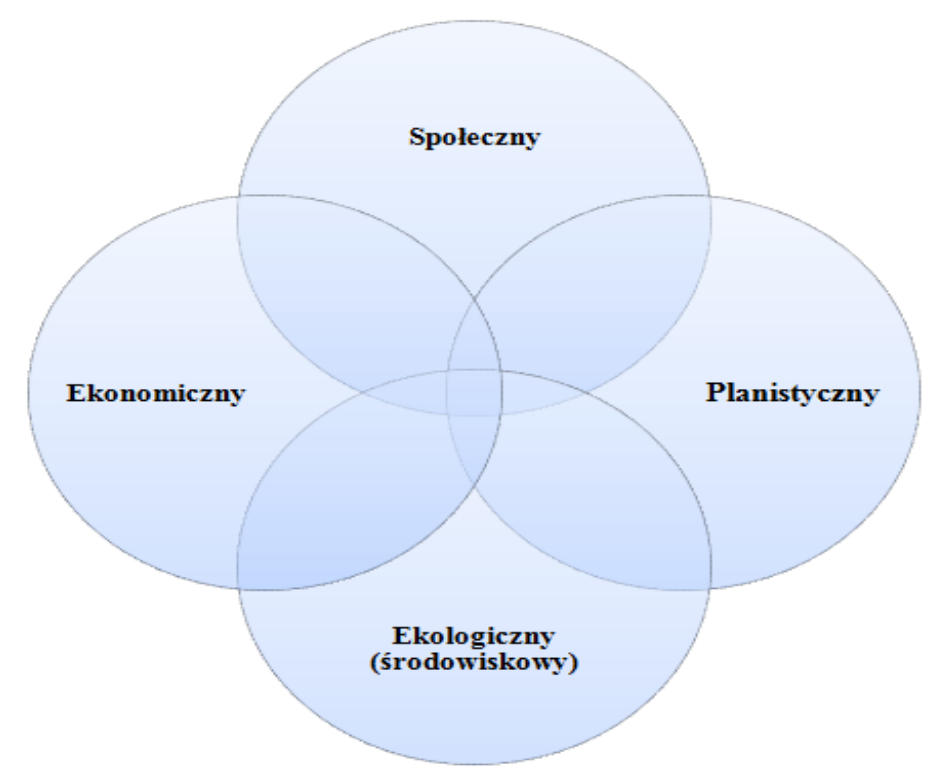

Rysunek 2. Zrównoważony rozwój samorządu - kluczowe aspekty

Źródło: Opracowanie własne na podstawie (http://www.ursa.com/...) 
Jednostki samorządu terytorialnego działające zgodnie z zasadami zrównoważonego rozwoju funkcjonują w oparciu o spójność czterech aspektów (Brzeszczak, Imiołczyk, Brzozowska 2015, s. 134-147). Poprzez aspekt społeczny należy rozumieć podstawową i najważniejszą składową, tj. mieszkańców wraz ze wszystkim wymiarami życia (potrzeby, cele, dążenia czy status społeczno-materialny) (Mierzejewska 2015, s. 6-7). Aspekt ekonomiczny z kolei to zabezpieczenie rozwoju poprzez możliwość minimalizacji ubóstwa, niedostatku czy braków społecznych. Kwestie finansowe są niezbędne do osiągnięcia lokalnego wzrostu gospodarczego. Aspekt ekologiczny należy natomiast postrzegać jako wyzwanie dla współczesnego samorządu, który dążąc do rozwoju, musi ograniczyć swoje negatywne oddziaływanie na środowisko, głównie poprzez zmniejszenie zanieczyszczeń. Władze lokalne muszą w sposób racjonalny wykorzystywać zasoby naturalne, a także jednocześnie budzić w społeczeństwie proekologiczne i odpowiedzialne postawy (Kuciński (red.) 2009, s. 54-55). Zasada zrównoważonego rozwoju jest niezbędnym elementem kształtowania polityki przestrzennej samorządu. Przestrzeń stanowi cenny zasób, który wykorzystywany bez ograniczeń może doprowadzić do zachwiania równowagi $\mathrm{w}$ danej jednostce. $\mathrm{W}$ związku $\mathrm{z}$ tym jest to jeden $\mathrm{z}$ ważniejszych aspektów zrównoważonego rozwoju jednostki samorządu terytorialnego. Ochrona środowiska naturalnego poprzez racjonalne wykorzystanie przestrzeni oraz przywracanie stanu początkowego elementom środowiskowym, przeciwdziałanie rozlewaniu się miast czy wykorzystanie ekologicznych rozwiązań w transporcie stanowi podstawę lokalnego rozwoju (Zaremba 2013, s. 266).

Podkreślenia wymaga także fakt, iż zrównoważony rozwój lokalny w sposób bezpośredni przekłada się na rozwój społeczno-gospodarczy szerszego obszaru. Zrównoważone inicjatywy podejmowane przez jednostki samorządu terytorialnego stanowią składową spójnego zrównoważonego rozwoju większej jednostki, w związku z tym miastom (jako odpowiednikom samorządów) nadaje się przydomki w odniesieniu do aspektów, które są dla nich najważniejsze, typu green cities, compact cities czy smart cities (FOB 2014, s. 2).

\section{Zrównoważone samorządy - dobre praktyki}

Poprzez samorząd rozwijający się w sposób zrównoważony należy rozumieć jednostkę, która gwarantuje swoim mieszkańcom odpowiednie i przyjazne warunki życia oraz funkcjonowania przy umiejętnym wykorzystaniu zasobów naturalnych. Jednocześnie zrównoważony samorząd ma na uwadze jakość życia przyszłych pokoleń oraz konieczność zapewnienia im dostępu do wszelkich dóbr. Zrównoważona jednostka samorządu terytorialnego w swym działaniu uwzględnia ze szczególnym naciskiem trzy aspekty: społeczeństwo, środowisko i gospodarkę. Coraz częściej przeprowadza się rankingi dotyczące wykorzystania zasad zrównoważonego rozwoju i funkcjonowania miast zgodnie $\mathrm{z}$ tą koncepcją. Samorządy odpowiedzialne za swoje inicjatywy zarówno w stosunku do społeczeństwa, jak i środowiska mają szansę każdego roku zawalczyć o miano miasta zrównoważonego.

Miasta najszybciej rozwijające się, jednak w sposób zrównoważony, w skali światowej przedstawione zostały w raporcie Arcadis Sustainable Cities Index 2015. 
W raporcie, typując lidera zrównoważonego rozwoju, uwzględniono trzy podstawowe kryteria (Sustainable Cities Index 2015, s. 6):

jakość życia - rozwój społeczny mieszkańców,

oddziaływanie na środowisko naturalne,

rozwój gospodarczy.

Jako główny cel opracowania raportu jego twórcy wskazali prezentację jednostek, które w sposób spójny rozwijają swój potencjał, przy jednoczesnym uwzględ-

- $\quad$ nieniu dobra społeczeństwa, jak i środowiska. Niestety cały czas mamy jeszcze do

- czynienia z zależnością, iż im wyższy stopień rozwoju społeczno-gospodarczego

- na danym terenie, tym niestety wyższy poziom zanieczyszczeń i negatywnego oddziaływania na otoczenie.

Biorąc pod uwagę powyższe kryteria, analizie poddano 100 miast, którym przyznano miejsca odpowiednio do stopnia funkcjonowania w sposób zrównoważony (Sustainable Cities Index 2016, s. 9). W Tabeli 2 przedstawiono 50 najwyżej ocenionych uczestników raportu (na 100 przebadanych).

Tabela 2. Miasta zbadane w raporcie Arcadis Sustainable Cities Index 2016 według przyznanego miejsca

\begin{tabular}{|l|c|l|c|}
\hline \multicolumn{1}{|c|}{ Miasto } & Miejsce & \multicolumn{1}{c|}{ Miasto } & Miejsce \\
\hline Zurych & 1. & New York & 26. \\
\hline Singapur & 2. & Wellington & 27. \\
\hline Sztokholm & 3. & Montreal & 28. \\
\hline Wiedeń & 4. & Antwerpia & 29. \\
\hline Londyn & 5. & Brisbane & 30. \\
\hline Frankfurt & 6. & Birmingham & 31. \\
\hline Seul & 7. & Melbourne & 32. \\
\hline Hamburg & 8. & Toronto & 33. \\
\hline Praga & 9. & Boston & 34. \\
\hline Monachium & 10. & Dublin & 35. \\
\hline Amsterdam & 11. & Glasgow & 36. \\
\hline Genewa & 12. & Warszawa & 37. \\
\hline Edynburg & 13. & Leeds & 38. \\
\hline Kopenhaga & 14. & San Francisco & 39. \\
\hline Paryż & 15. & Bruksela & 40. \\
\hline Hong Kong & 16. & Makao & 41. \\
\hline Berlin & 17. & Mediolan & 42. \\
\hline Kambera & 18. & Seatle & 43. \\
\hline Rotterdam & 19. & Waszyngton & 44. \\
\hline Madryt & 20. & Tokyo & 45. \\
\hline Sydney & 21. & Lizbona & 46. \\
\hline Rzym & 22. & Lion & 47. \\
\hline Vancouver & 23. & Taipei & 48. \\
\hline Barcelona & 24. & Denver & 49. \\
\hline Manchester & 25. & Los Angeles & 50. \\
\hline
\end{tabular}

Źródło: (Sustainable Cities Index 2015, s. 9) 
W drodze analizy wyników raportu zadowalającym okazuje się fakt, iż niemal całkowicie w skład pierwszej dziesiątki wchodzą zrównoważone miasta europejskie. Jednostki te są zarządzane w taki sposób, aby pogodzić interesy społeczne, gospodarcze, jak i środowiskowe. Warto zwrócić uwagę, jak sytuacja na podium zmieniła się w stosunku do 2015 roku. Wówczas praktycznie nieuwzględniane były kraje skandynawskie, gdzie w tegorocznej edycji Sztokholm uplasował się od razu na trzecim miejscu. W celu porównania sytuacji z rokiem 2016 poniżej przedstawiono 10 pierwszych miejsc z 2015 roku (Tabela 3).

Tabela 3. Wybrane miasta zbadane w raporcie Arcadis Sustainable Cities Index 2015 wedlug przyznanego miejsca

\begin{tabular}{|l|c|l|c|}
\hline \multicolumn{1}{|c|}{ Miasto } & Miejsce & \multicolumn{1}{c|}{ Miasto } & Miejsce \\
\hline Frankfurt & 1. & Berlin & 6. \\
\hline Londyn & 2. & Seul & 7. \\
\hline Kopenhaga & 3. & Hong Kong & 8. \\
\hline Amsterdam & 4. & Madryt & 9. \\
\hline Rotterdam & 5. & Singapur & 10. \\
\hline
\end{tabular}

Źródło: (Sustainable Cities Index 2015, s. 12)

Pogarszająca się sytuacja miast azjatyckich na tle reszty świata może wynikać m.in. ze zmian klimatycznych, którymi są dotykane, ciągle wzrastającą urbanizacją, szybkim rozwojem przemysłu nieprzychylnego zarówno środowisku, jak ispołeczeństwu, nieetycznych warunków pracy, jak i życia.

Ponieważ Sztokholm odnotował znaczący awans, plasując się na trzecim miejscu w rankingu, warto przyjrzeć się inicjatywom, w które się angażował na przestrzeni ostatnich lat. Aby rozwój szwedzkich samorządów był zrównoważony, władze samorządowe skupiają uwagę na potrzebach zgłaszanych nie tylko przez lokalne społeczeństwo i gospodarkę, ale także środowisko naturalne, które w konsekwencji zmian klimatycznych jest coraz bardziej wymagające. Zaznaczyć należy także fakt, iż w 2010 roku Sztokholm został uznany za Zieloną Stolicę Europy. Miasto posiada strategię dotyczącą zrównoważonego rozwoju „Wizja Sztokholm 2030" (http://ec.europa.eu/environment/europeangreencapital/wp-content/uploads/ 2011/...), która określa podstawowe cele, takie jak odpowiedzialność za mieszkańców przy dynamicznym, ale zrównoważonym rozwoju w oparciu o poszanowanie zasobów naturalnych.

Poniżej przedstawiono najciekawsze inicjatywy podejmowane przez szwedzki samorząd.

1. Sztokholmski Morski Port Królewski (Maciejewska 2013).

Władze samorządowe realizują projekt rewitalizacji dawnych terenów poprzemysłowych. Na terenach uprzednich doków ma powstać niezwykle nowoczesna i wysoce zrównoważona dzielnica. Głównym celem przekształcenia tych zdegradowanych terenów w obszar przyjazny mieszkańcom jest zatrzymanie rozszczepiania się miasta i zagarniania nowych zielonych terenów pod inwestycje zurbanizowane. Cała inicjatywa jest bardzo ambitna i niezwykle kosztowna, gdyż nakłady szacuje się na kwotę ok. 2 miliardów euro (Maciejewska 2013). Zgodnie z założe- 
niami strategicznymi oraz sposobem zarządzania władz lokalnych cały proces „,budowania" nowej dzielnicy ma być przeprowadzony zgodnie z zasadami zrównoważonego rozwoju. Taka ma też być sama dzielnica, która będzie musiała spełnić następujące wymagania:

Komunikacja miejska oraz transport lokalny mają być w $100 \%$ zrównoważone.

Również zarządzanie mediami ma być zrównoważone - wykorzystywane tam źródła energii mają zaspokoić potrzeby rezydentów tej jednostki przy jednoczesnym nieobciążaniu środowiska naturalnego.

Zostanie wprowadzony system recyclingu, który pozwoli na jak najskuteczniejsze wykorzystanie surowców przeznaczonych do utylizacji.

Projekt nie może mieć negatywnego wpływu na sąsiadujące tereny chronione.

Architektura oraz projekt urbanistyczny będą spójne $\mathrm{z}$ otaczającą przestrzenią oraz z estetyką terenów objętych ochroną.

Inicjatywa ta jest odpowiedzią na problemy społeczne. Władze, chcąc zatrzymać mieszkańców, dla których istotne są kwestie proekologiczne i prospołeczne, inwestują w zrównoważone rozwiązania.

2. Nowoczesny system geotermalny (Biznestuba.pl 2015).

Na głównym dworcu w Sztokholmie wykorzystywany jest nowoczesny system geotermalny. Proces polega na zbieraniu energii z ciepła generowanego przez podróżnych, które następnie wykorzystywane jest do ogrzewania biurowca zlokalizowanego w pobliżu. Ciepło, dzięki wykorzystaniu specjalnej instalacji, jest przekazywane do zbiornika wody grzewczej. Z kolei woda z jeziora Klara służy do chłodzenia wspomnianego budynku. Reasumując - w budynku wykorzystywana jest w pełni ekologiczna technologia grzewczo-chłodząca.

3. Redukcja stopnia zanieczyszczenia powietrza (http://ec.europa.eu/environment/ europeangreencapital/wp-content/uploads/2013/...)

Zgodnie z założeniami przyjętej strategii władze miejskie dążą do całkowitej eliminacji zanieczyszczeń pochodzących z paliw kopalnych do roku 2050. Aby osiągnąć zamierzony cel, wprowadzonych zostało wiele innowacji, m.in.:

Zwiększony został udział źródeł odnawialnych w ciepłowniach do $70 \%$.

Niemal 70\% gospodarstw podłączonych zostało do miejskiej sieci ciepłowniczej.

Biogaz produkuje się z odpadów żywnościowych (i proces ten ma być

rozszerzany).

Wprowadzony został bardzo nowoczesny system recyclingu odpadów, polegający na podziemnym próżniowym transporcie odpadów.

Tabor miejski napędzany jest paliwami odnawialnymi oraz energią pochodzącą ze źródeł odnawialnych.

Wprowadzony został spójny i zsynchronizowany system komunikacji miejskiej, dzięki czemu mieszkańcy oraz turyści bardzo chętnie z niego korzystają.

Stwierdzić można, iż Sztokholm jest miastem całkowicie zrównoważonym. Strategia zarządzania miastem charakteryzuje się kompleksowym podejściem zarówno do kwestii społecznych i gospodarczych, jak i środowiskowych. Zintegrowany system zarządzania pozwala na realizację zadań proekologicznych $\mathrm{w}$ ramach zadań samorządowych z wykorzystaniem budżetu miasta. Dzięki temu możliwe 
jest dokładne planowanie, organizowanie, koordynowanie i monitorowanie zadań zrównoważonych. Zaznaczenia wymaga fakt, iż już w latach 70. w Sztokholmie powstał i funkcjonował pierwszy program ekologiczny (http://ec.europa.eu/ environment/ europeangreencapital/wp-content/uploads/2013/...).

\section{Podsumowanie}

Zrównoważony rozwój odgrywa istotną rolę w zarządzaniu samorządem. Każda jednostka samorządu terytorialnego dbająca o swoich interesariuszy musi w swych strategiach rozwoju uwzględniać trzy główne aspekty: społeczeństwo, gospodarkę i środowisko rozszerzone o kwestie planistyczne. Równowaga zachowań pomiędzy tymi elementami przy spójnych procesach zarządzania gwarantuje jednostce zrównoważony i szybki rozwój. Z przeprowadzanych badań wynika, iż samorządy coraz większą wagę przywiązują do kwestii prospołecznych i proekologicznych. Przykładem odpowiedzialnego podejścia do kwestii rozwoju jest Sztokholm, jako przedstawiciel krajów skandynawskich. Miasto angażuje się w różnorodne działania przy zaangażowaniu wysokich nakładów finansowych, mając na celu osiągnięcie zamierzeń wyznaczonych w strategiach długofalowych. Co ważne - władze dążą do realizacji wyznaczonych celów przy pełnym wsparciu kluczowych interesariuszy.

\section{Literatura}

1. Biznestuba.pl (2015), 7 przykładów inicjatyw na rzecz zrównoważonego rozwoju w Szwecji, http://biznestuba.pl/featured/7-przykladow-inicjatyw-na-rzecz-zrownowazonego-rozwojuw-szwecji/ (dostęp: 10.10.2016).

2. Brzeszczak A., Imiołczyk J., Brzozowska A. (2015), Zarządzanie zrównoważonym rozwojem $w$ aspekcie samorzadu terytorialnego - studium przypadku miasta Częstochowy, [w:] Krawczyk-Sokołowska I., Lemańska-Majdzik A., Ziółkowska B. (red.), Zrównoważony rozwój w zarządzaniu, Wydawnictwo Wydziału Zarządzania Politechniki Częstochowskiej, Częstochowa, s. 134-147.

3. Europejska Karta Samorządu Terytorialnego, sporządzona w Strasburgu dnia 15 października 1985 r. (Dz.U. 1994 nr 124 poz. 607).

4. FOB (2014), Biznes na rzecz zrównoważonych miast, „Analiza Tematyczna”, nr 2, http://odpowiedzialnybiznes.pl/wp-content/uploads/2014/07/Analiza-tematyczna-_Biznesna-rzecz-zr\%C3\%B3wnowa\%C5\%BConych-miast.pdf (dostęp: 02.10.2017).

5. Gawroński H. (2010), Zarzadzanie strategiczne w samorządach lokalnych, Wolters Kluwer, Warszawa.

6. Griffin R.W. (2005), Podstawy zarzadzania organizacjami, Wydawnictwo Naukowe PWN, Warszawa.

7. Griffin R.W. (2013), Podstawy zarzadzania organizacjami, Wydawnictwo Naukowe PWN, Warszawa.

8. http://ec.europa.eu/environment/europeangreencapital/wp-content/uploads/2011/05/egcbrochure-stockholm_pl.pdf(dostęp: 05.10.2016).

9. http://ec.europa.eu/environment/europeangreencapital/wp-content/uploads/2013/02/ENV-15 -007-factsheet-PL-web.pdf (dostęp: 10.10.2016).

10. http://www.ursa.com/en-us/drivingsustainability/pages/global-need-for-sustainabledevelopment. aspx (dostęp: 07.10.2016). 
11. Kot S., Brzeziński S. (2015), Market Orientation Factors in Sustainable Development and Corporate Social Responsibility, „Asian Journal of Applied Sciences”, Vol. 8, Issue 2, s. 101-112. DOI: 10.3923/ajaps.2015.101.112

12. Kronenberg J., Bergier T. (red.) (2010), Wyzwania zrównoważonego rozwoju w Polsce, Fundacja Sendzimira, Kraków.

13. Kuciński K. (red.) (2009), Strategie przedsiębiorstw wobec wymogów zrównoważonego rozwoju, Oficyna Wydawnicza SGH, Warszawa.

14. Maciejewska B. (2013), Oto Sztokholm, ,Zielone Miasto. Magazyn zielonej polityki, cywilizacji i stylu życia”, nr 2, http://zielonemiasto.org/oto-sztokholm/ (dostęp: 10.10.2016).

15. Mierzejewska L. (2015), Zrównoważony rozwój miast - wybrane sposoby pojmowania, koncepcje i modele, „Problemy Rozwoju Miast, Kwartalnik Naukowy Instytutu Rozwoju Miast", R. 12, z. 2, s. 5-11.

16. Noworól A. (2006), Zarządzanie w samorządzie. ABC samorządu terytorialnego, Fundacja Rozwoju Demokracji Lokalnej, Warszawa.

17. Noworól A. (2007), Planowanie rozwoju terytorialnego $w$ skali regionalnej i lokalnej, Wydawnictwo Uniwersytetu Jagiellońskiego, Kraków.

18. Sekuła A. (red.) (2007), Wdrożenie lokalnych strategii rozwoju - problemy i bariery, „Zeszyty Naukowe Uniwersytetu Szczecińskiego nr 471. Ekonomiczne Problemy Usług” nr 11, s. $197-206$.

19. Skowron-Grabowska B. (2014), Strategiczne uwarunkowania zrównoważonego transportu przedsiębiorstw, „Gospodarka Materiałowa \& Logistyka”, nr 3, s. 24-32.

20. Sustainable Cities Index 2015. Balancing the Economic, Social and Environmental Needs of the World's Leading Cities, Arcadis.

21. Ustawa z dnia 27 kwietnia 2001 r. Prawo ochrony środowiska (Dz.U. $2001 \mathrm{nr} 62$ poz. 627).

22. Wojciechowski E. (2003), Zarządzanie w samorzadzie terytorialnym, Difin, Warszawa.

23. Zaremba A. (2013), Planistyczne aspekty polityki przestrzennej a podstawy ochrony środowiska w kontekście zrównoważonego rozwoju obszarów wiejskich, „Journal of Agribusiness and Rural Development", Vol. 2(28), s. 262-270.

24. Ziółkowski M. (2003), Zarzadzanie strategiczne w samorządzie gminnym, „Prace Naukowe Akademii Ekonomicznej we Wrocławiu" nr 979, s. 52-67.

\title{
SUSTAINABLE DEVELOPMENT - TREND OR ELEMENT OF MODERN LOCAL GOVERNMENT MANAGEMENT
}

\begin{abstract}
The aim of the article is to point out the importance of the concept of sustainable development in local government management. In the current economic situation, local governments are forced to compete with each other. They compete in the economic, social, cultural as well as ecological areas. In order to meet the demands and needs expressed by the various stakeholder groups, local governments engage in many different initiatives. Both the local community as well as investors or local entrepreneurs require that the local government is managed in an efficient and sustainable manner. That is why local government units are increasingly using the concept of sustainable development in the management process and at all its levels.
\end{abstract}

Keywords: local government, local government management, sustainable development, sustainable development of local government 